\title{
MACRONUTRIENT ACCUMULATION AND PARTIONING IN FERTIGATED SWEET PEPPER PLANTS
}

\author{
Francisco Fernando Noronha Marcussi ${ }^{1}$; Roberto Lyra Villas Bôas ${ }^{2 *}$; Leandro José Grava de \\ Godoy $^{2}$; Rumy Goto ${ }^{3}$ \\ ${ }^{1}$ UNESP/FCA - Depto. de Engenharia Rural, C.P. 237 - 18603-970 - Botucatu, SP - Brazil. \\ ${ }^{2}$ UNESP/FCA - Depto. de Recursos Naturais / Ciência do Solo. \\ ${ }^{3}$ UNESP/FCA - Depto. de Produção Vegetal / Horticultura. \\ *Correponding author 〈rlvboas@fca.unesp.br>
}

\begin{abstract}
Information on nutrient demand during each growth stage is essential for efficient application of nutrients. A pot experiment was carried out with a Typic Hapludox under greenhouse conditions in Botucatu, SP, Brazil, aiming was to determine nutrient uptake and partition of sweet pepper plants, cultivar Elisa in randomized block design with four replications. The fertigation was simulated through 2-L PET bottles (neck down with a tube and a flow regulator at the end, simulating a drip irrigation system). Four plants per replication were collected at eight growth stages $(0,20,40,60,80,100,120$ and 140 days after the seedling transplant - DAT). The period of largest extraction of nutrients for the plant occurred from 120 to 140 DAT, which coincides with the highest accumulation of dry phytomass. The highest $\mathrm{Mg}$ and $\mathrm{Ca}$ accumulation occurred in the leaves, while N, K, S and P were mostly accumulated in the fruits. Only 8 to $13 \%$ of the total amount of the accumulated macronutrientes at 140 DAT were absorbed up to the 60th DAT. Between the $61^{\text {st }}$ and $100^{\text {th }}$ DAT, $\mathrm{K}$ was the most absorbed macronutrient $(60 \%$ of the macronutrients accumulated during the whole cycle). $\mathrm{P}, \mathrm{Ca}$ and $\mathrm{S}$ were the most absorbed nutrients at the end of the cycle. Considering rates (g per plant), the most absorbed macronutrients were: $\mathrm{N}(6.6)>\mathrm{K}(6.4)>\mathrm{Ca}(2.6)>\mathrm{Mg}(1.3)>\mathrm{S}(1.1)>\mathrm{P}(0.7)$. Key words: Capsicum annuum L., irrigation, greenhouse, growth
\end{abstract}

\section{ACÚMULO E PARTIÇÃO DE MACRONUTRIENTES EM PLANTAS DE PIMENTÃO FERTIRRIGADAS}

\begin{abstract}
RESUMO: A demanda de nutrientes em cada etapa do crescimento de uma planta é uma informação essencial para que se possa aplicar os nutrientes de forma mais eficiente. Com objetivo de determinar a marcha de absorção e a partição de macronutrientes em plantas de pimentão cultivar Elisa foi conduzido um experimento em vasos de $29 \mathrm{dm}^{3}$ contendo um Latossolo Vermelho aluminoférrico sob condições de cultivo protegido em Botucatu, SP em delineamento experimental em blocos ao acaso com quatro repetições. A fertirrigação foi simulada utilizando garrafas $(2 \mathrm{~L})$ com uma mangueira e um controlador de vazão na extremidade. Foram coletadas quatro plantas por repetição, em oito épocas $(0,20,40,60,80,100,120$, e 140 dias após o transplantio das mudas DAT). O período de maior extração de nutrientes pela planta ocorreu de 120 aos 140 DAT coincidindo com o maior acúmulo de fitomassa seca. O maior acúmulo de $\mathrm{Mg}$ e $\mathrm{Ca}$ ocorreu nas folhas, enquanto, $\mathrm{N}, \mathrm{K}$, $\mathrm{S}$ e o $\mathrm{P}$ foram mais acumulados nos frutos. Apenas 8 a $13 \%$ da quantidade total dos macronutrientes acumulados em 140 DAT foram absorvidos até os 60 DAT. Dos 61 aos 100 DAT o K foi o macronutriente mais absorvido (60\% do total acumulado no ciclo); $\mathrm{P}, \mathrm{Ca}$ e $\mathrm{S}$ foram mais absorvidos no final do ciclo. Os macronutrientes mais absorvidos foram, em g por planta: $\mathrm{N}(6,6)>\mathrm{K}(6,4)>\mathrm{Ca}(2,6)>\mathrm{Mg}(1,3)>\mathrm{S}(1,1)>\mathrm{P}(0,7)$.

Palavras-chave: Capsicum annuum L., irrigação, ambiente protegido, crescimento
\end{abstract}

\section{INTRODUCTION}

Sweet pepper (Capsicum annuum L.) is one of the most consumed vegetables in Brazil, and is better adjusted and most frequently produced under greenhouse conditions (Melo, 1997). Cultivation of sweet pepper in greenhouses demands intensive use of agri-inputs and labour. Moreover, this activity is part of a dynamic market in which seasonal prices fluctuate, demanding from the producer rigorous planning for both crop production and technology in order to decrease production risks and increase profits. Fertigation is one of the techniques utilized to achieve this goal. It consists of adding nutrients according to plan needs to the irrigation water, particularly through sprinkler and drip systems (Villas Bôas, 2001). Nutrient absorption depends on the plant phenological stage and is enhanced during flowering, fruit formation and growth (Silva, 1998). Information on these absorption rates improves the fertigation efficiency (Bar-Yosef, 1999). 
For planning fertilization it is also very important to be aware of new genotypes and growth features in different conditions, since dry matter and nutrient accumulations are closely associated to each other, so that one deficit harms other, directly or indirectly (Benincasa, 1988). The optimal nutrient absorption curve (nutrient accumulation curve) determines both the rate for application of a specific nutrient to avoid possible deficits or luxury uptake, and the adequate proportion of nutrients. One of the first studies on the nutrient absorption curves in Brazil was carried out by Haag et al. (1970) for sweetpepper (variety "casca dura") grown in nutrient solution. Further studies on nutrition, however, are necessary as a consequence of constant genetic changes of the crop, made to improve quality (Fernandes \& Haag, 1972).

Application of adequate nutrient rates decreases salinity problems which otherwise could negatively affect production in closed crop systems (Raij, 1993). The aim of the present study was to determine nutrient accumulation and partition along the whole cycle of a fertigated Elisa sweet pepper crop grown in greenhouse, as a support for the improvement of fertilization programs.

\section{MATERIAL AND METHODS}

The experiment was carried out inside a greenhouse (plastic tunnel; $20 \mathrm{~m}$ long, $7 \mathrm{~m}$ wide, and $2.5 \mathrm{~m}$ high) in Botucatu, SP, Brazil (22 ${ }^{\circ} 51^{\prime}$ 'S, 48 $26^{\circ}$ 'W; altitude $786 \mathrm{~m}$ ). Air temperature and relative humidity were recorded by a portable thermo hygrograph placed $1.5 \mathrm{~m}$ above ground.

Amianthus pots $\left(29-\mathrm{dm}^{3}\right)$ were filled with a sandy-clayey Typic Hapludox and placed inside the plastic tunnel. The physical and chemical properties of the soil were determined according to EMBRAPA (1997) and Raij et al. (1987), obtaining the following results: $\mathrm{pH}$ $\left(\mathrm{CaCl}_{2}\right) 4.0 ; 24 \mathrm{~g} \mathrm{dm}^{-3} \mathrm{OM} ; 3 \mathrm{mg} \mathrm{dm}{ }^{-3} \mathrm{P}$ (resin); $\mathrm{H}^{+}+\mathrm{Al}^{+3}$, $\mathrm{K}, \mathrm{Ca}$ and $\mathrm{Mg}$ concentrations of 61, 0.4, 1 and $1 \mathrm{mmol}$ $\mathrm{dm}^{-3}$, respectively; base saturation (BS) of 3\%; and sand, clay and silt compositions of 670,260 and $70 \mathrm{~g} \mathrm{~kg}^{-1}$, respectively.

Based on Raij et al. (1996), after adding dolomite lime (86\% Total Neutralizing Relative Power) until the BS reached $80 \%$, each pot received $150 \mathrm{~g} \mathrm{P} \mathrm{dm}^{-1}$ of soil, as thermal phosphate $\left(17 \% \mathrm{P}_{2} \mathrm{O}_{5}, 20 \% \mathrm{Ca}, 9 \% \mathrm{Mg}\right.$ and $6 \% \mathrm{~S}), 117 \mathrm{mg} \mathrm{K}$ as $\mathrm{KCl}$, and also $150 \mathrm{~g}$ of an organic compound. Pots were watered to $70 \%$ of the volume corresponding to the $0.033 \mathrm{MPa}$ matric potential covered with a plastic sheet and maintained for 30 days.

Each pot received two seedlings of Elisa sweet pepper (Capsicum annuum L.), cultivated in trays containing commercial substratum, on July $19^{\text {th }}, 1999$ (66 days after sowing). A distance of $0.24 \mathrm{~m}$ between seedlings within rows and $1.30 \mathrm{~m}$ row spacing were used. The development of the sweet pepper plants was limited to three stems and then the first flower (relative to the first internode) was removed. Structures for plant sustentation and growth were set up. To simulate a local irrigation system, a 2-L PET bottle was used for each pot. This bottle was suspended upside down, with removed bottom to allow inflow of water and dissolved fertilizers. A pipe was connected to the PET bottle cap, which had a water-flow controller to allow a dripping rate of $2 \mathrm{~L} \mathrm{~h}^{-1}$. Drippers were installed $10 \mathrm{~cm}$ above the plant base.

Nutrient rates applied through fertigation were strictly related to levels used in the field and were applied after the $54^{\text {th }}$ day after transplantation (DAT). The fertigation scheme consisted of: $1.9 \mathrm{~g}$ calcium nitrate diluted into $250 \mathrm{~mL}$ of water per plant $(0.285 \mathrm{~g}$ nitrogen and $0.361 \mathrm{~g}$ calcium) up to the 66 DAT. After the fourth application (66 DAT), the level of nitrogen was increased to $0.392 \mathrm{~g}$ per plant $(2.72 \mathrm{~g}$ calcium nitrate) and then the potassium $(\mathrm{KCl})$ application was initiated $(0.295 \mathrm{~g} \mathrm{~K}$ per plant). During the $10^{\text {th }}$ and $14^{\text {th }}$ applications (102 and 122 DAT, respectively), boron $\left(0.150 \mathrm{mg} \mathrm{B}\right.$ plant $\left.^{-1}\right)$ and manganese $\left(0.132 \mathrm{mg} \mathrm{Mn} \mathrm{plant}^{-1}\right)$ were added in the form of borax and manganese sulphate, respectively. $\mathrm{N}$ and $\mathrm{K}$ were applied every 4 days, (16 and 13 applications, respectively), until 133 DAT, corresponding to a total of $5.95 \mathrm{~g} \mathrm{~N}$ and $3.84 \mathrm{~g} \mathrm{~K}$ plant $^{-1}$.

A randomized block design with four replications and eight sampling dates was used. Samples of plants were taken every 20 days, from day 0 to 140 DAT. In each of these eight samplings dates, four plants were collected per repetition (two pots with two plants each).

Plants were collected by cutting their base close to the ground. Plant height, first-bifurcation height and number of leaves and bifurcations were recorded in the laboratory. Fruit collections started at 80 DAT, and the fruits produced by the plants that would be collected later (at 100, 120, and 140 DAT) were removed from the plant for fresh and dry matter determinations (these data were included for determination of the plant dry matter at the collection moment). Fruits larger than $10 \mathrm{~cm}$ in length or $7 \mathrm{~cm}$ in diameter were classified as commercial fruits, and smaller ones as non-commercial.

Plants were washed and taken apart into individual leaves, stems, roots and fruits, and then dried in a forced-air oven at $65^{\circ} \mathrm{C}$. Each dried plant organ was weighed (dry matter), ground and submitted to chemical analyses according to Malavolta et al. (1997). Based on dry matter and nutrient concentrations, absolute and relative growth rates and nutrient levels were determined for each plant organ.

Mean and standard error were calculated for each variable. The levels of plant-accumulated macronutrients from 40 to 140 DAT were analyzed by linear regression using the software SigmaPlot for Windows v.8.0 (SPSS Inc.); plant age (DAT) was the independent variable. 
Models (equation) were selected for best statistical adjustment ( $\mathrm{F}$ test, $5 \%$ ), best fit $\left(\mathrm{R}^{2}\right)$, and biological significance.

\section{RESULTS AND DISCUSSION}

Accumulation of dry matter by sweet pepper was slow until 60 DAT and then increased as the fructification began (Figure 1). Haag et al. (1970), Fernandes \& Haag (1972) and Fontes \& Monnerat (1984) observed slow growth until 75 DAT, but they used varieties rather than hybrid genotypes.

The maximal growth of sweet pepper was not reached until 140 DAT (Figure 1), in contrast to reports by Crespo-Ruiz et al. (1988) who found the maximal dry matter accumulation point at 100 DAT for cv Cubanelle in Puerto Rico. After 120 DAT, the plant dry matter accumulation was greatly increased, probably because of the great fruit harvest (60\% of the total commercial fruit production), which occurred up to 110 DAT (Table 1), thus reducing plant drains (Taiz \& Zieger, 1991). These processes may have stimulated new vegetative growth (root, leaves and stem) that was indicated also by increased plant height and number of bifurcations and leaves (Table 2). Villas Bôas (2001) studied this same hybrid under similar conditions and found taller plants $(109 \mathrm{~cm})$ with fewer leaves (55) and more bifurcations (34) at 174 DAT. Panelo (1995) reported that the Vidi hybrid had the lowest plant length $(50$ to $70 \mathrm{~cm}$ ) after two month of ongoing harvest $(\sim 143$ DAT), while Elisa hybrid presented intermediate length ( 80 to $90 \mathrm{~cm}$ ) at this time, in comparison to the other studied hybrids.

The first-bifurcation height reached $19 \mathrm{~cm}$ at the end of the observations. This may depend on the cultivation system (Faria Jr., 1997), but may also be altered by the number of conducted stalks (Tivelli et al., 1998). An excess of fertilizers, mainly nitrogenous, may promote excessive plant growth and, consequently, the first bifur- cation. For Elisa hybrids of the same age, Tivelli (1999) found $22.4 \mathrm{~cm}$ height for the first bifurcation.

After transplantation, the plant remains in an adjustment period up to 20 DAT, named "establishment phase" (Crespo-Ruiz et al., 1988), during which dry matter is accumulated mostly in the leaves. After that (from 20 to 60 DAT), dry matter is allocated to the stem and roots (Figure 2), enlarging the radicular system. Dry matter accumulated in the leaves decreased from $64.5 \%$ at

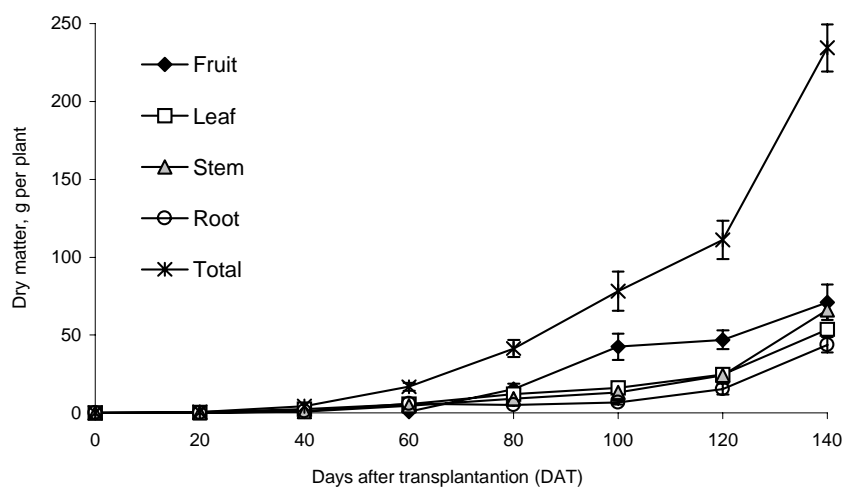

Figure 1 - Accumulation of dry matter (total and for each organ) by sweet pepper fertigated at different days after transplantation (DAT).

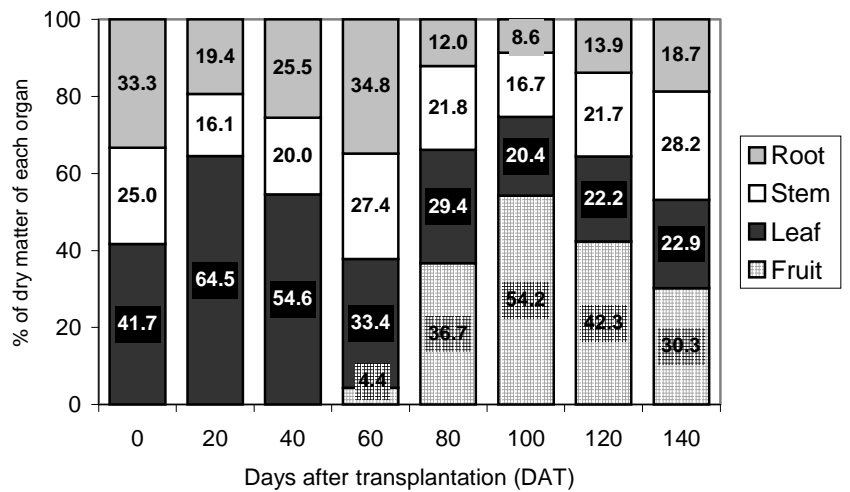

Figure 2 - Percentual distribution of dry matter in each organ of sweet pepper fertigated at different days after transplantation.

Table 1 - Sweet pepper fruit production performance according to days after transplantation.

\begin{tabular}{|c|c|c|c|c|c|}
\hline $\begin{array}{l}\text { Days after } \\
\text { transplantation }\end{array}$ & $\begin{array}{l}\text { No. of commercial } \\
\text { fruits }\end{array}$ & & & Lenght & Diameter \\
\hline & & g & g per fruit & $-\cdots$ & --- \\
\hline $60^{1}$ & -- & -- & -- & -- & -- \\
\hline 80 & 2 & 70.86 & 35.43 & 10.8 & 6.1 \\
\hline 97 & 5 & 365.31 & 73.06 & 11.1 & 7.4 \\
\hline 100 & 1 & 46.51 & 46.51 & 10.7 & 6.8 \\
\hline 110 & 2 & 266.41 & 133.21 & 10.9 & 7.7 \\
\hline 120 & 1 & 53.50 & 53.50 & 8.8 & 6.5 \\
\hline 135 & 1 & 172.81 & 172.81 & 10.8 & 8.5 \\
\hline 140 & 1 & 82.31 & 82.31 & 10.8 & 7.0 \\
\hline Total & 13 & 1267.70 & 1267.70 & 10.5 & 7.1 \\
\hline
\end{tabular}

${ }^{1}$ harvesting either without ripe fruits and without commercial fruits. 
20 DAT to $20.4 \%$ at 100 DAT (Figure 2), probably as a function of dry matter allocation to the stem and root until 60 DAT and then to fruit formation (from 60 to 100 DAT).

The most intense fructification from 80 to 100 DAT increased dry matter in fruits $(54.2 \%$ at 100 DAT) instead of leaves, stems and roots. During this period, the number of bifurcations did not increase, but plant height and number of leaves increased slightly (Figure 2 ). At the fructification period (60 to $100 \mathrm{DAT}$ ), the absolute growth rate (AGR) of plants increased from 0.6 to $1.8 \mathrm{~g}$ plant day ${ }^{-1}$, mainly because fruits increased from 0.7 to 14 g plant day $^{-1}$ (Figure 3 ).

Plant AGR decreased slightly (1.6 g plant day $\left.{ }^{-1}\right)$ from 100 to 120 DAT, followed by a high increase (6.2 $\mathrm{g}$ plant day ${ }^{-1}$ ) from 120 to 140 DAT, probably as a result of generalized growth of all plant organs. The maximal AGR found by Dias (2000) for the hybrid Elisa until 224 DAT (6.85 $\mathrm{g} \mathrm{plant}^{-1}$ ) was similar to that herein described. The dry matter distribution at 140 DAT was similar to that observed at 80 DAT when harvesting was initiated, with about $70 \%$ of dry matter accumulated in roots, leaves and steams (Figure 2).

The period of highest nutrient extractions occurred from 120 to 140 DAT, coinciding with the greatest accumulation of dry matter (Figure 1). During this period the accumulated $\mathrm{N}$ levels doubled from 3 to $6 \mathrm{~g} \mathrm{~N}$ day $^{-1}$ (Figure 4). On the other hand, absorption of $\mathrm{P}, \mathrm{Mg}$ and $\mathrm{S}$ increased only after $80 \mathrm{DAT}$, while absorption of $\mathrm{N}, \mathrm{K}$ and $\mathrm{Ca}$ increased after 60 DAT (Figures 4 and 5). The higher accumulation of $\mathrm{Mg}$ and $\mathrm{Ca}$ occurred in the leaves, but $\mathrm{N}, \mathrm{K}, \mathrm{S}$ and $\mathrm{P}$ were mostly accumulated in the fruits (Tables 3 and 4 ).

The accumulation curves plotted in Figures 4 and 5 allow the estimation of the amount of extracted nutrients by the plants during each developmental phase, starting from 40 DAT. This indicate the need of fertilizer per fertigation, which for sweet pepper crops should begin between at 40 to 50 DAT, since fertilization during the

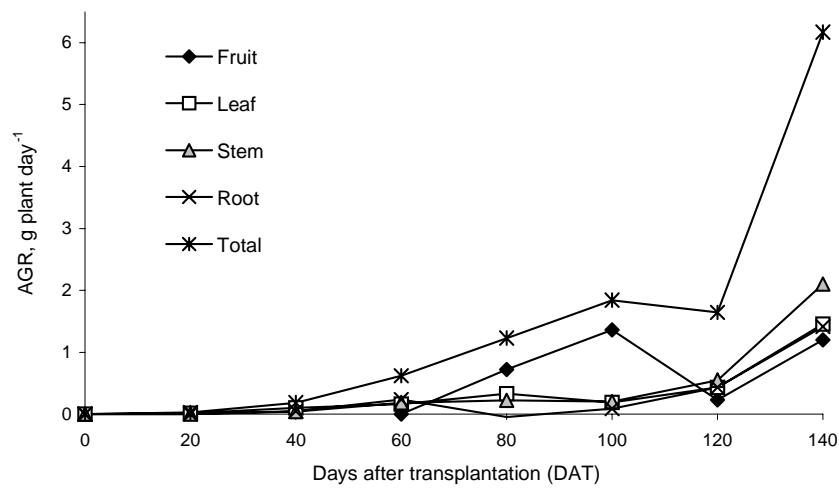

Figure 3 - Absolute growth rate (AGR) for the whole plant (total) and for each plant organ for sweet peppers fertigated at different days after transplantation. transplantation period, made mainly with manure, meets plant demands efficiently (Villas Bôas, 2001).

$\mathrm{N}$ and $\mathrm{K}$ were the most extracted macronutrients, with similar rates of extraction for $\mathrm{N}$, followed by $\mathrm{Ca}$, $\mathrm{Mg}, \mathrm{S}$ and $\mathrm{P}$ in decreasing order of concentration (Table 3). The levels of extracted nutrients found by Silva (1998) for the Mayata hybrid sweet pepper $(\mathrm{N}=5.6 \mathrm{~g} ; \mathrm{P}=0.5$ $\mathrm{g} ; \mathrm{K}=10.0 \mathrm{~g} ; \mathrm{Ca}=3.5 \mathrm{~g} ; \mathrm{Mg}=1.7 \mathrm{~g}$ and $\mathrm{S}=1.0 \mathrm{~g}$ ) were similar to those observed here, except for K, which was 56\% higher. Haag et al. (1970), Santiago \& Goyal (1985), Graifenberg et al. (1985), Dias (2000) and Villas Bôas (2001) also reported greater extraction of $\mathrm{K}$ in comparison to $\mathrm{N}$. This might be a consequence of using different cultivars and/or luxury uptake, since in the present study there was no K deficiency; and $\mathrm{K}$ levels in the leaves are within the range considered normal by Trani et al. (1996), or even above this range, as considered by Malavolta et al. (1997) (Table 5). According to these two later studies, the levels of the other macronutrients are within the adequate range for sweet pepper at 100 DAT (complete flowering), which is the indicated period for sampling leaves for chemical analyses.

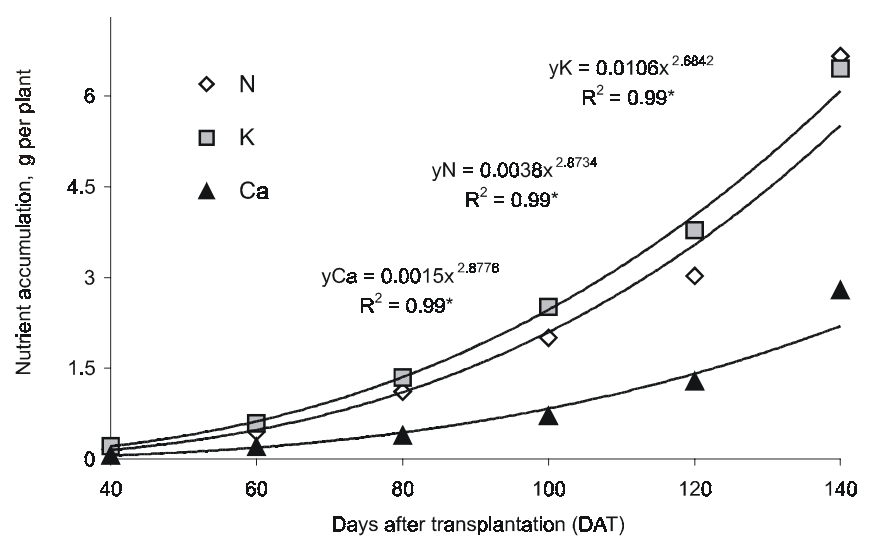

Figure 4 - Adjusted curves for accumulation of N, K e Ca in sweet pepper plants fertigated from 40 to 140 days after transplantation. *significant $\mathrm{R}^{2}$ by $\mathrm{F}$ test at $\alpha=5 \%$.

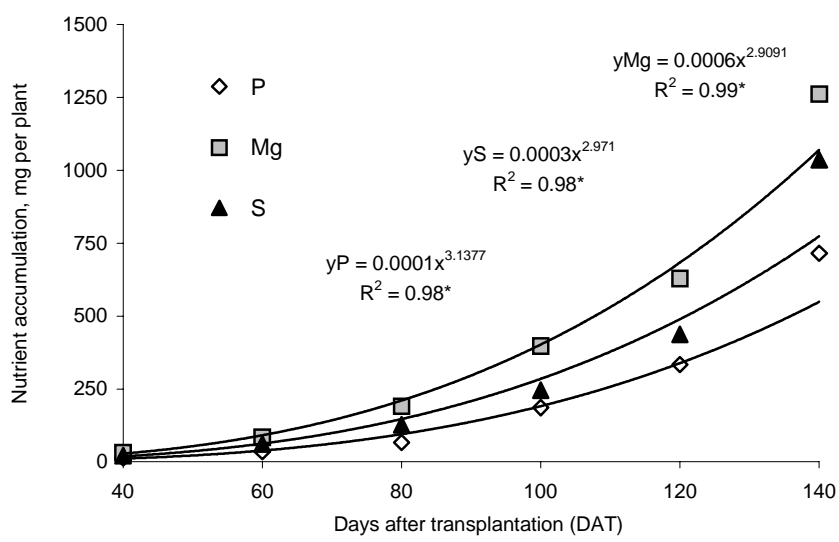

Figure 5 - Adjusted curves for accumulation of $\mathrm{P}, \mathrm{Mg}$, and $\mathrm{S}$ in sweet pepper plants fertigated from 40 to 140 days after transplantation. *significant $\mathrm{R}^{2}$ by $\mathrm{F}$ test at $\alpha=5 \%$. 
$\mathrm{P}$ was the most extracted element by the fruits, followed by N, S and $\mathrm{K}$ at similar percentages (Table 6). On the other hand, $\mathrm{Ca}$ and $\mathrm{Mg}$ were the nutrients least extracted by the fruits. Dias (2000) found the same macronutrient exportation order for the Elisa sweet pepper: $\mathrm{P}=60 \% ; \mathrm{N}=40 \% ; \mathrm{K}=40 \% ; \mathrm{S}=35 \% ; \mathrm{Ca}=24 \%$ and $\mathrm{Mg}=18 \%$.
From the total amount of macronutrients accumulated until 140 DAT, only 8 to $13 \%$ were absorbed up to 60 DAT (Table 7). Between 61 and 100 DAT, $\mathrm{K}$ was the most absorbed macronutrient $(60 \%$ of the total accumulated in the cycle); $\mathrm{P}, \mathrm{Ca}$ and $\mathrm{S}$ were more absorbed at the end of the cycle (from 101 to 140 DAT).

Table 2 - Means $( \pm \mathrm{SE})$ of plant and first-bifurcation heights, number of bifurcations and leaves according to days after transplantation.

\begin{tabular}{lcccccccc}
\hline Characteristics & \multicolumn{8}{c}{ Days After Transplantation } \\
\cline { 2 - 8 } & 0 & 20 & 40 & 60 & 80 & 100 & 120 \\
\hline Plant height $(\mathrm{cm})$ & 8.4 & 10.8 & $20.1 \pm 2.1$ & $42.1 \pm 2.0$ & $52.1 \pm 2.9$ & $58.0 \pm 4.1$ & $68.1 \pm 3.6$ & $79.9 \pm 3.1$ \\
1 st bifurcation height $(\mathrm{cm})$ & 1.5 & 1.5 & $17.5 \pm 1.0$ & $18.7 \pm 1.1$ & $18.7 \pm 1.3$ & $19.0 \pm 1.1$ & $19.3 \pm 1.4$ & $18.6 \pm 1.8$ \\
$\mathrm{~N}^{\circ}$ of bifurcation & 1 & 2 & $2 \pm 0.5$ & $4 \pm 0.6$ & $5 \pm 0.8$ & $5 \pm 0.9$ & $8 \pm 1.0$ & $11 \pm 1.2$ \\
$\mathrm{~N}^{\circ}$ of leaves & 6 & 13 & $21 \pm 3$ & $54 \pm 8$ & $76 \pm 7$ & $102 \pm 10$ & $164 \pm 34$ & $247 \pm 23$ \\
\hline
\end{tabular}

$\mathrm{SE}=$ standard error

Table 3 - Accumulation of nutrients (mean $\pm \mathrm{SE}$ ) in total dry matter and plant parts of fertigated sweet pepper, according to days after transplantation (DAT).

\begin{tabular}{|c|c|c|c|c|c|}
\hline \multirow{2}{*}{ Nutrient } & \multirow{2}{*}{ Plant part } & \multicolumn{4}{|c|}{ Days after transplantation } \\
\hline & & 0 & 20 & 40 & 60 \\
\hline & & 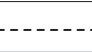 & - & lant --..-..-- & ( \\
\hline \multirow{5}{*}{$\mathrm{N}$} & Total & $2.2^{(1)}$ & $21.0^{(1)}$ & $162 \pm 33$ & $455 \pm 84$ \\
\hline & Leaf & 1.1 & 14.8 & $110 \pm 22$ & $218 \pm 32$ \\
\hline & Fruit & & & & $37 \pm 9$ \\
\hline & Stem & 0.4 & 2.6 & $22 \pm 4$ & $92 \pm 20$ \\
\hline & Root & 0.7 & 3.6 & $30 \pm 13$ & $108 \pm 26$ \\
\hline \multirow{5}{*}{$\mathrm{P}$} & Total & 1.3 & 2.5 & $13.7 \pm 3.1$ & $34.7 \pm 7.1$ \\
\hline & Leaf & 0.8 & 1.9 & $8.8 \pm 2.0$ & $14.5 \pm 3.1$ \\
\hline & Fruit & & & & $5.7 \pm 1.2$ \\
\hline & Stem & 0.2 & 0.2 & $2.2 \pm 0.5$ & $8.6 \pm 2.3$ \\
\hline & Root & 0.3 & 0.3 & $2.7 \pm 1.2$ & $5.8 \pm 1.1$ \\
\hline \multirow{5}{*}{$\mathrm{K}$} & Total & 5.9 & 35.2 & $219 \pm 45$ & $594 \pm 98$ \\
\hline & Leaf & 2.6 & 24.0 & $140 \pm 28$ & $330 \pm 54$ \\
\hline & Fruit & & & & $30 \pm 7$ \\
\hline & Stem & 1.5 & 5.8 & $45 \pm 7$ & $231 \pm 39$ \\
\hline & Root & 1.9 & 5.5 & $34 \pm 18$ & $29 \pm 6$ \\
\hline \multirow{5}{*}{$\mathrm{Ca}$} & Total & 1.7 & 10.9 & $64 \pm 9$ & $205 \pm 32$ \\
\hline & Leaf & 1.0 & 8.8 & $48 \pm 7$ & $123 \pm 21$ \\
\hline & Fruit & & & & $8 \pm 1$ \\
\hline & Stem & 0.4 & 1.3 & $7 \pm 1$ & $32 \pm 6$ \\
\hline & Root & 0.3 & 0.8 & $9 \pm 3$ & $42 \pm 7$ \\
\hline \multirow{5}{*}{$\mathrm{Mg}$} & Total & 0.6 & 5.7 & $31.4 \pm 6.5$ & $83.7 \pm 14.8$ \\
\hline & Leaf & 0.3 & 4.3 & $24.3 \pm 5.3$ & $57.0 \pm 9.5$ \\
\hline & Fruit & & & & $4.5 \pm 0.8$ \\
\hline & Stem & 0.1 & 0.9 & $4.4 \pm 0.4$ & $21.3 \pm 4.7$ \\
\hline & Root & 0.1 & 0.6 & $2.8 \pm 1.1$ & $0.9 \pm 0.5$ \\
\hline \multirow{5}{*}{ S } & Total & 0.6 & 2.4 & $21.3 \pm 4.2$ & $61.4 \pm 9.6$ \\
\hline & Leaf & 0.3 & 1.6 & $13.3 \pm 2.7$ & $29.6 \pm 4.6$ \\
\hline & Fruit & & & & $3.9 \pm 0.6$ \\
\hline & Stem & 0.2 & 0.3 & $3.2 \pm 0.5$ & $18.5 \pm 2.4$ \\
\hline & Root & 0.1 & 0.4 & $4.8 \pm 1.9$ & $9.5 \pm 3.5$ \\
\hline
\end{tabular}

${ }^{(1)}$ Because of insufficient material, samples of blocks were mixed for analyses, not allowing mean and SE evaluations. SE $=$ standard error 
Table 4 - Accumulation of nutrients (mean $\pm \mathrm{SE}$ ) in dry matter of total plant and plant parts of fertigated sweet pepper, according to days after transplantation (DAT).

\begin{tabular}{|c|c|c|c|c|c|}
\hline \multirow{2}{*}{ Nutrient } & \multirow{2}{*}{ Plant part } & \multicolumn{4}{|c|}{ Days after transplantation } \\
\hline & & 80 & 100 & 120 & 140 \\
\hline \multicolumn{6}{|c|}{ - } \\
\hline \multirow{5}{*}{$\mathrm{N}$} & Total & $1110 \pm 97$ & $2000 \pm 342$ & $3029 \pm 337$ & $6661 \pm 77$ \\
\hline & Leaf & $453 \pm 51$ & $595 \pm 82$ & $929 \pm 65$ & $2122 \pm 174$ \\
\hline & Fruit & $429 \pm 72$ & $1029 \pm 255$ & $1363 \pm 179$ & $2432 \pm 483$ \\
\hline & Stem & $124 \pm 12$ & $210 \pm 23$ & $403 \pm 42$ & $1090 \pm 98$ \\
\hline & Root & $103 \pm 14$ & $167 \pm 22$ & $335 \pm 70$ & $1017 \pm 77$ \\
\hline \multirow{5}{*}{$\mathrm{P}$} & Total & $66.2 \pm 11.2$ & $185.9 \pm 39.8$ & $333.4 \pm 79.3$ & $715.6 \pm 4.5$ \\
\hline & Leaf & $17.0 \pm 2.9$ & $27.1 \pm 4.7$ & $60.9 \pm 9.2$ & $124.1 \pm 6.5$ \\
\hline & Fruit & $36.5 \pm 8.8$ & $128.3 \pm 33.3$ & $197.4 \pm 52.5$ & $362.1 \pm 26.7$ \\
\hline & Stem & $7.4 \pm 1.3$ & $16.4 \pm 2.5$ & $40.9 \pm 11.7$ & $128.8 \pm 24.0$ \\
\hline & Root & $5.2 \pm 0.8$ & $14.1 \pm 3.1$ & $34.2 \pm 8.1$ & $100.7 \pm 5.0$ \\
\hline \multirow{5}{*}{ K } & Total & $1353 \pm 189$ & $2512 \pm 466$ & $3785 \pm 218$ & $6450 \pm 130$ \\
\hline & Leaf & $490 \pm 80$ & $663 \pm 82$ & $1205 \pm 118$ & $2041 \pm 266$ \\
\hline & Fruit & $486 \pm 87$ & $1262 \pm 363$ & $1645 \pm 186$ & $2041 \pm 181$ \\
\hline & Stem & $327 \pm 47$ & $439 \pm 36$ & $704 \pm 66$ & $1734 \pm 124$ \\
\hline & Root & $50 \pm 10$ & $148 \pm 20$ & $231 \pm 69$ & $635 \pm 130$ \\
\hline \multirow{5}{*}{$\mathrm{Ca}$} & Total & $391 \pm 50$ & $717 \pm 109$ & $1283 \pm 108$ & $2790 \pm 65$ \\
\hline & Leaf & $253 \pm 42$ & $439 \pm 68$ & $781 \pm 62$ & $1276 \pm 234$ \\
\hline & Fruit & $34 \pm 2$ & $127 \pm 25$ & $165 \pm 38$ & $444 \pm 76$ \\
\hline & Stem & $61 \pm 10$ & $102 \pm 11$ & $211 \pm 7$ & $64 \pm 82$ \\
\hline & Root & $44 \pm 5$ & $49 \pm 11$ & $127 \pm 22$ & $427 \pm 65$ \\
\hline \multirow{5}{*}{$\mathrm{Mg}$} & Total & $190.5 \pm 36.4$ & $396.8 \pm 68.6$ & $629.5 \pm 68.4$ & $1261.7 \pm 58.2$ \\
\hline & Leaf & $109.2 \pm 21.5$ & $176.9 \pm 27.7$ & $277.4 \pm 25.3$ & $365.2 \pm 89.9$ \\
\hline & Fruit & $31.5 \pm 5.8$ & $102.9 \pm 23.8$ & $132.8 \pm 16.0$ & $234.3 \pm 27.5$ \\
\hline & Stem & $41.3 \pm 10.2$ & $80.2 \pm 11.4$ & $142.1 \pm 7.9$ & $406.2 \pm 50.2$ \\
\hline & Root & $8.5 \pm 1.4$ & $36.9 \pm 10.4$ & $77.3 \pm 23.9$ & $256.0 \pm 58.2$ \\
\hline \multirow{5}{*}{ S } & Total & $126.5 \pm 21.4$ & $246.2 \pm 39.0$ & $437.3 \pm 26.2$ & $1036.4 \pm 16.5$ \\
\hline & Leaf & $39.6 \pm 8.8$ & $56.3 \pm 7.6$ & $118.1 \pm 10.8$ & $263.2 \pm 33.2$ \\
\hline & Fruit & $43.3 \pm 7.5$ & $117.7 \pm 31.9$ & $168.0 \pm 19.6$ & $365.6 \pm 57.0$ \\
\hline & Stem & $31.8 \pm 7.4$ & $48.5 \pm 2.2$ & $102.3 \pm 3.9$ & $264.2 \pm 19.2$ \\
\hline & Root & $11.8 \pm 1.4$ & $23.7 \pm 4.3$ & $48.9 \pm 16.1$ & $143.3 \pm 16.5$ \\
\hline
\end{tabular}

$\overline{\mathrm{SE}}=$ standard error

Table 5 - Concentration of nutrients in leaves (mean $\pm \mathrm{SE}$ ), according to the cycle of fertigated sweet pepper.

\begin{tabular}{|c|c|c|c|c|c|c|c|c|}
\hline \multirow{2}{*}{ Nutrient } & \multicolumn{8}{|c|}{ Days after transplantation } \\
\hline & 0 & 20 & 40 & 60 & 80 & 100 & 120 & 140 \\
\hline & $\cdots$ & & 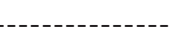 & $----\xi$ & $--\cdot$ & $\cdots$ & --- & ---- \\
\hline $\mathrm{N}$ & 211 & 371 & $46 \pm 2$ & $39 \pm 1$ & $37 \pm 1$ & $37 \pm 1$ & $38 \pm 1$ & $46 \pm 1$ \\
\hline $\mathrm{P}$ & 15.5 & 4.8 & $3.7 \pm 0.2$ & $2.6 \pm 0.3$ & $1.4 \pm 0.2$ & $1.7 \pm 0.1$ & $2.5 \pm 0.2$ & $2.7 \pm 0.3$ \\
\hline $\mathrm{K}$ & 52 & 60 & $59 \pm 2$ & $59 \pm 3$ & $40 \pm 3$ & $42 \pm 4$ & $49 \pm 4$ & $44 \pm 3$ \\
\hline $\mathrm{Ca}$ & 20 & 22 & $20 \pm 1$ & $22 \pm 1$ & $21 \pm 1$ & $28 \pm 1$ & $32 \pm 2$ & $28 \pm 3$ \\
\hline $\mathrm{Mg}$ & 6.1 & 10.7 & $10.2 \pm 0.6$ & $10.2 \pm 0.5$ & $9.0 \pm 0.8$ & $11.1 \pm 0.6$ & $11.3 \pm 0.6$ & $7.9 \pm 1.3$ \\
\hline S & 6.5 & 4.1 & $5.6 \pm 0.2$ & $5.3 \pm 0.2$ & $3.3 \pm 0.4$ & $3.5 \pm 0.3$ & $4.8 \pm 0.6$ & $5.7 \pm 0.4$ \\
\hline
\end{tabular}

Production of commercial fruit of green sweet pepper up to 140 DAT reached $1.3 \mathrm{~kg}$ per plant (Table 1). Tivelli (1999) found similar results for Elisa hybrids cultivated in a closed system, which reached about 1.1 kg per plant. Higher yield in commercial fruits was ob- tained as a result of larger space between plants $(0.48 \mathrm{x}$ $1.30 \mathrm{~m}$ ) (Villas Bôas, 2001) and because of the extended fruit-harvesting period (5 months) (Melo, 1997). In these cases, the commercial fruit yield reached 2.5 and $3.85 \mathrm{~kg}$ per plant, respectively. 
Table 6 - Quantities of nutrients extracted by the plant and exported by fertigated sweet pepper during the 140-day cycle.

\begin{tabular}{lccc}
\hline \multirow{2}{*}{ Nutrient } & \multicolumn{2}{c}{ Quantity of nutrients } & $\begin{array}{c}\text { Percentage exported } \\
\text { by the fruits }\end{array}$ \\
\cline { 2 - 3 } & Extracted & Exported & $\%$ \\
\hline & g per plant & g per fruit & 36.5 \\
$\mathrm{~N}$ & 6.66 & 2.43 & 50.6 \\
$\mathrm{P}$ & 0.72 & 0.36 & 31.6 \\
$\mathrm{~K}$ & 6.45 & 2.04 & 15.9 \\
$\mathrm{Ca}$ & 2.79 & 0.44 & 18.6 \\
$\mathrm{Mg}$ & 1.26 & 0.23 & 35.3 \\
$\mathrm{~S}$ & 1.04 & 0.37 & \\
\hline
\end{tabular}

Table 7 - Percent macronutrients uptake during the cycle of fertigated sweet pepper.

\begin{tabular}{lrcc}
\hline \multirow{2}{*}{ Nutrient } & \multicolumn{3}{c}{ Days after transplantation } \\
\cline { 2 - 4 } & 0 to 60 & 61 to 100 & 101 to 140 \\
\hline & $---\%$ of nutrients taken up at this period --.-- \\
$\mathrm{N}$ & 9.60 & 46.7 & 43.71 \\
$\mathrm{P}$ & 7.28 & 35.2 & 57.48 \\
$\mathrm{~K}$ & 13.24 & 59.9 & 26.84 \\
$\mathrm{Ca}$ & 10.07 & 39.7 & 50.21 \\
$\mathrm{Mg}$ & 9.62 & 46.5 & 43.83 \\
$\mathrm{~S}$ & 8.27 & 36.0 & 55.77 \\
\hline
\end{tabular}

\section{ACKNOWLEDGMENTS} 99/02880-9).

To FAPESP for an undergraduate fellowship $\left(\mathrm{N}^{\circ}\right.$

\section{REFERENCES}

BAR-YOSEF, B. Advances in fertigation. In: SPARKS, D.L. (Ed.) Advances in agronomy. New York: Academic Press, 1999. p.1-77.

BENINCASA, M.M.P. Análise de crescimento de plantas: noções básicas. Jaboticabal: FUNEP, 1988. 42p.

CRESPO-RUIZ, M.; GOYAL, M.R.; BÁEZ, C.C.; RIVERA, L.E. Nutrient uptake and growth characteristics of nitrogen fertigated sweet peppers under drip irrigation and plastic mulch. Journal of Agricultural of University of Puerto Rico, v.72, p.575-584, 1988.

DIAS, E.N. Absorção de nutrientes, crescimento vegetativo e produção de frutos maduros de pimentão, em estufa. Viçosa: Universidade Federal de Viçosa, 2000. 70p. (Dissertação - Mestrado).

EMPRESA BRASILEIRA DE PESQUISA AGROPECUÁRIA. Manual de métodos de análise de solo. Rio de Janeiro: EMBRAPA, CNPS, 1997. 212p.

FARIA JR., M.J.A. Avaliação de híbridos de pimentão no cultivo protegido microclima sob estufas de diferentes arquiteturas e da eficácia de diferentes materiais plásticos como cobertura do solo. Jaboticabal: FCAV/ UNESP, 1997. 104p. (Tese - Doutorado).
FERNANDES, P.D.; HAAG, H.G. Nutrição mineral de hortaliças. XXII. Diferenças nutricionais entre variedades de pimentão (Capsicum annиum L.) Anais da ESALQ, v.28, p.145-151, 1972.

FONTES, P.C.R.; MONNERAT, P.H. Nutrição mineral e adubação das culturas de pimentão e pimenta. Informe Agropecuário, v.10, p.25-31, 1984.

GRAIFENBERG, A.; PETSAS, S.; LENZI, I. Crescita e asportazione degli elementi nutritive nel peperone allevato in serra fredda. Coltore Protette, v.12, p.33-38, 1985.

HAAG, H.P.; HOMA, P.; KIMOTO, T. Nutrição Mineral de hortaliças: VAbsorção de nutrientes pela cultura do pimentão. O Solo, v.62, p.7-11, 1970.

MALAVOLTA, E.; VITTI, G.C.; OLIVEIRA, S.C. Avaliação do estado nutricional das plantas: princípios e aplicações. 2.ed. Piracicaba: Potafos, 1997. 317p.

MELO, A.M.T. Análise genética de caracteres de fruto em híbridos de pimentão. Piracicaba: ESALQ/USP, 1997. 112p. (Tese - Doutorado).

PANELO, M. Adaptabilidad de cultivares de pimiento a condiciones de cultivo protegido. Horticultura Brasileira, v.13, p.101, 1995. Suplemento. Resumo 209.

PAPADOPOULOS, I. Nitrogen fertigation of greenhouse-grown french beans. Communications in Soil Science and Plant Analysis, v.17, p.893-903, 1986.

RAIJ, B. V. Princípios de correção e de adubação para mudas e para produção comercial. In: SIMPÓSIO SOBRE NUTRIÇÃO E ADUBAÇÃO DE HORTALIÇAS, 1990, Jaboticabal. Anais. Piracicaba: Potafos, 1993, p.75-84.

RAIJ, B.; QUAGGIO, J.A.; CANTARELLA, H.; FERREIRA, M.E.; LOPES, A.S.; BATAGLIA, O.C. Análise química do solo para fins de fertilidade. Campinas: Fundação Cargill, 1987. 170p.

RAIJ, B.; CANTARELLA, H.; QUAGGIO, J.A.; FURLANI, A.M.C. Recomendações de adubação e calagem para o estado de São Paulo. 2.ed. Campinas: Instituto Agronômico; Fundação IAC, 1996. 285p. (Boletim Técnico, 100).

SANTIAGO, C.L.; GOYAL, M.R. Nutrient uptake and solute movement in drip irrigated summer peppers. Journal of Agricultural of the University of Puerto Rico, v.69, p.63-68, 1985.

SILVA, M.A.G. Efeito do nitrogênio e potássio na produção e nutrição do pimentão em ambiente protegido. Piracicaba: ESALQ/USP, 1998. 86p. (Tese - Doutorado).

TAIZ, L.; ZEIGER, E. Plant physiology. Redwwood City: The BenjaminCummings Publishing Company, 1991. 559p.

TIVELLI, S.W. Avaliação de híbridos e sistemas de condução na cultura do pimentão (Capsicum annuum L.) vermelho em ambiente protegido. Botucatu: FCA/UNESP, 1999. 240p. (Tese - Doutorado).

TIVELLI, S.W.; OLIVEIRA, J.A.S.; GOTO, R. Caracterização morfológica de híbridos de pimentão vermelho indicado para o cultivo em ambiente protegido. Horticultura Brasileira, v.16, p.148, 1998. Suplemento. Resumo 351.

TRANI, P.E.; MELO, A.M.T.; PASSOS, F.A.; TAVARES, M.; NAGAI, H.; SCIVITTARO, W.B. Berinjela, jiló, pimenta-hortícola e pimentão. In: RAIJ, B.; CANTARELLA, H.; QUAGGIO, J.A.; FURLANI, A.M.C. (Ed.) Recomendação de adubação e calagem para o Estado de São Paulo. 2.ed. Campinas: IAC; Fundação IAC, 1996. p.150-151. (Boletim Técnico, 100).

VILLAS BÔAS, R.L. Doses de nitrogênio para o pimentão aplicadas de forma convencional e através da fertirrigação. Botucatu: FCA/UNESP, 2001. 123p. (Tese - Livre Docência).

Received February 07, 2003

Accepted November 24, 2003 